Editor's Note: Miller and Gold et al. provide additional pearls that may help clinicians suspect a central origin of a fourth nerve palsy. In response to Yufe, Saposnik et al. clarify the methodology of their study on Stroke Prognostication using Age and NIH Stroke Scale (NIHSS). The latter 2 combined are, according to the authors, the 2 major predictors of stroke outcomes.

Chafic Karam, MD, and Robert C. Griggs, $M D$ visual sensory disturbance: a sign of contralateral dorsal midbrain disease. J Clin Neuroophthalmol 1991;11:169-172.

3. Girkin CA, Perry JD, Miller NR. A relative afferent pupillary defect without any visual sensory defect. Arch Ophthalmol 1998;116:1544-1545.

4. Makki AA, Newman NJ. A trochlear stroke. Neurology 2005;65:1989.

5. Thurtell MJ, Tomsak RL, Leigh RJ. Upbeat-torsional nystagmus and contralateral fourth-nerve palsy due to unilateral dorsal pontomesencephalic lesion. Ann NY Acad Sci 2009;1164:476-478.

\section{STROKE PROGNOSTICATION USING AGE AND NIH STROKE SCALE: SPAN-100}

NERVE PALSIES

Neil R. Miller, Baltimore: In their otherwise superb teaching article on diagnosis of central fourth nerve palsies, Gold et al. ${ }^{1}$ missed the opportunity to emphasize an important sign: an ipsilateral or contralateral relative afferent pupillary defect (RAPD) unassociated with any decrease in visual acuity, reduced color vision, or visual field defect. In the setting of an apparently isolated fourth nerve palsy, the presence of an RAPD indicates involvement of the brachium of the superior colliculus and almost always indicates that the fourth nerve palsy is central in origin. ${ }^{2,3}$

\section{Author Response: Daniel R. Gold, Philadelphia;} Robert Shin, Baltimore; Steven Galetta, New York: We thank Dr. Miller for the reminder that the combination of an RAPD and a fourth nerve palsy should alert the clinician to the possibility of a central lesion, implying an interruption of pupillary axons traveling through the brachium of the superior colliculus adjacent to the fourth nerve nucleus or fascicle. Similarly, the combination of upbeat or upbeat-torsional nystagmus and a fourth nerve palsy also suggests a central (nuclear or fascicular) localization, with the nystagmus presumably attributable to disruption of the anterior canal pathways at the level of the brachium conjunctivum. ${ }^{4,5}$

(C) 2013 American Academy of Neurology

1. Gold DR, Shin RK, Galetta S. Pearls and oy-sters: central fourth nerve palsies. Neurology 2012;79:e193-e196.

2. Elliott D, Cunningham ET Jr, Miller NR. Fourth nerve paresis and ipsilateral relative afferent pupillary defect without
Robert Yufe, Toronto: I read the article by Saposnik et al. ${ }^{1}$ with interest. Without a control group with a positive Stroke Prognostication using Age and NIHSS (SPAN)-100, it is difficult to know whether giving tissue plasminogen activator $(\mathrm{tPA})$ is of benefit. Studies have shown that the elderly benefit from tPA, so that leaves the severity of the stroke as measured by the NIHSS Score as the main determinant of a good outcome.

Nevertheless, the article is a useful tool with which to counsel families and substitute decision-makers who must often decide for the aphasic patient whether to give tPA in SPAN-100 patients.

Author Response: Gustavo Saposnik, Toronto: We thank Dr. Yufe for his comments regarding our article. ${ }^{1}$ Regarding the control group for the SPAN-100, figures 1 and 2 and table 2 provide a comparison of multiple outcomes between SPAN-100 patients receiving tPA and placebo. SPAN-100 patients receiving tPA had higher risk of intracerebral hemorrhage compared to SPAN-100 in the placebo group. No significant benefit was observed in functional clinical outcomes, allowing for a small sample size. Age and stroke severity are the 2 major predictors of stroke outcomes. Although these results need to be validated in a larger dataset, they are useful when counseling ischemic stroke patients and their families.

(C) 2013 American Academy of Neurology

1. Saposnik G, Guzik AK, Reeves M, Ovbiagele B, Johnston SC. Stroke prognostication using age and NIH Stroke Scale: SPAN100. Neurology 2013;80:21-28. 


\section{Neurology}

\section{Stroke prognostication using age and NIH Stroke Scale: SPAN-100}

Robert Yufe and Gustavo Saposnik

Neurology 2013;81;603

DOI 10.1212/01.wnl.0000433418.06773.33

This information is current as of August 5, 2013

\section{Updated Information \&} Services

References

Permissions \& Licensing

Reprints including high resolution figures, can be found at: http://n.neurology.org/content/81/6/603.2.full

This article cites 1 articles, 1 of which you can access for free at: http://n.neurology.org/content/81/6/603.2.full\#ref-list-1

Information about reproducing this article in parts (figures,tables) or in its entirety can be found online at:

http://www.neurology.org/about/about_the_journal\#permissions

Information about ordering reprints can be found online:

http://n.neurology.org/subscribers/advertise

Neurology ${ }^{\circledR}$ is the official journal of the American Academy of Neurology. Published continuously since 1951, it is now a weekly with 48 issues per year. Copyright (C 2013 American Academy of Neurology. All rights reserved. Print ISSN: 0028-3878. Online ISSN: 1526-632X.



